Jurnal PAIRaden Falah

Vol. 2, No. 1, (Januari 2020): 74-86

\title{
ANALISIS FAKTOR-FAKTOR YANG MEMENGARUHI HASIL BELAJAR ANAK TUNAGRAHITA PADA MATA PELAJARAN PENDIDIKAN AGAMA ISLAM DI SLB WARAQIL JANNAH KEC. X KOTO PANINJAUAN SUMATERA BARAT
}

\section{Yarmeli}

Universitas Islam Negeri Raden

Fatah Palembang

yarmelimuchtar12@gmail.com

Nyayu Khodijah

Universitas Islam Negeri Raden

Fatah Palembang

nyayukhodijah@radenfatah.ac.id

Muhammad Fauzi

Universitas Islam Negeri Raden

Fatah Palembang

muhammadfauzi@radenfatah.ac.id

\begin{abstract}
This study aims to find out and analyze what factors influence the learning outcomes of children with intellectual disabilities and dual mental retardation in Islamic religious education subjects at SLB Waraqil Jannah Kec. X Koto Pan Overview West Sumatra. The study only focused on three factors, the first is the type of disability, intelligence level and learning motivation factors. This research is a quantitative research. The sample in this study amounted to 29 mentally retarded children and multiple mentally retarded children. Data collection methods used were questionnaire and documentation methods which were then analyzed using the Chi Squaer formula. The results of the study showed that there was no influence of the three research variables with the acquisition of a disability value of 1.19225, the price of Kai Squared was much smaller on the significance table of $5 \%$ or $1 \%$ or $40.113<1.19255<46.963$. The acquisition value of the intelligence level of 5.4452558 which is relatively low than the price of Kai Square is much smaller in the significance table of $5 \%$ or $1 \%$ or $40.113<5.4452558<46.963$. The value of learning motivation of 0.117347379 which is relatively low than the price of Kai Squared is much smaller in the significance table of $5 \%$ or $1 \%$ or $41,337<0,117347379<48,278$.
\end{abstract}

Keywords: Factors, Learning Outcomes, Children with Developmental Disabilities, Islamic Religious Education Subjects 


\section{PENDAHULUAN}

Tunagrahita adalah istilah yang digunakan untuk menyebut anak yang mempunyai kemampuan intelektual di bawah rata-rata. Dalam kepustakaan bahasa asing digunakan istilah-istilah mental retardition, mentally retaede, mental deficiency, mental defective, dan lain-lain. ${ }^{1}$ Penyandang tuna grahita atau cacat grahita adalah mereka yang memiliki kemampuan intelektual atau IQ dan keterampilan penyesuaian di bawah rata-rata teman seusianya. Ketunaan ini di kelompokkan menjadi: (1) golongan ringan atau mampu didik, (2) golongan sedang atau mampu lihat, dan (3) golongan cacat grahita berat atau idiot. ${ }^{2}$

Selain pengelompokan di atas ada pula pengelompokan berdasarkan kelainan jasmani yang disebut tipe klinis. Tipe-tipe klinis yang dimaksud adalah sebagai berikut : (1) Down Syndome (Mongoloid) anak tunagrahita jenis ini disebut demikian karena memiliki raut muka menyerupai orang ,omgol demgam ,atau sipit dan mirimg, lidah tebal suka menjulur ke luar, telinga kecil, kulit kasar, susunan gigi kurang baik. (2) Kretin (Cebol) memiliki ciri dengan badan gemuk dan pendek, kaki dan tangan pendek dan bengkok, kulit kering, tebal dan keriput, rambut kering, bibir dan lidah tebal, kelopak mata kecil, telapak tangan dan kaki tebal, pertumbuhan gigi terlambat. (3) Hydrocephalus memiliki ciri kepala besar, raut muka kecil, pandangan dan pendengaran tidak sempurna, mata kadang-ladang juling. (4) Microcephalus miliki ciri ukuran kepala yang kecil. (4) Macrocephalus memiliki ciri ukuran kepala lebih besar dari ukuran normal. ${ }^{3}$

Sebagian besar masalah yang beraitan dengan kegagalan belajar siswa, digali dan dikritisi oleh para pendidiknya secara empirik melalui fenomena eksternal kepribadian siswa. Guru umumnya hanya menyoroti perilaku kegagalan belajar siswa bersifat sesaat dan muncul secara instan bersifat eksternal, jarang sekali dihubungkan dengan faktor-faktor internal, bersemayam dalam diri siswa. Boleh jadi kadang-kadang mereka hubungkan saja dengan faktor kehidupan siswa,

\footnotetext{
${ }^{1}$ T. Sutjihati Somantri, Psikologi Anak Luar Biasa (Bandung: Redaksi Refika, 2006), hlm. 103.

${ }^{2}$ Nur'aeni, Intervensi Dini Bagi Anak Bermasalah (Jakarta: Rineka Cipta, 2004), hlm. 105.

${ }^{3}$ I.G.A.K. Wardani, dkk, Pengantar Pendidikan Anak Berkebutuhan Khusus, (Banten : Universitas Terbuka, Modul cet. 1, 2013), hlm. 6.10
} 
Vol. 2, No. 1, (Januari 2020): 74-86

seperti siswa yang gagal umumnya berhubungan dengan pekerjaan di luar sekolah. $^{4}$

Dalam proses pembelajaran, ada faktor-faktor yang turut mempengaruhi hasil belajar seseorang, baik orang normal maupun orang yang memiliki kekurangan yang dalam hal ini adalah orang yang termasuk ke dalam golongan tunagrahita. Mulyono Abdurrahman mengatakan bahwa ada dua faktor dalam proses belajar, yaitu: faktor internal dan faktor eksternal. Faktor ini meliputi gangguan atau kurang mampu psiko dan fisik siswa yakni: (1) yang bersifat kognitif, seperti rendahnya kapasitas intelektual, (2) bersifat afektif, labilnya emosi dan sikap, (3) bersifat psikomotor, seperti terganggunya alat-alat indera penglihatan, pendengaran (mata dan telinga). Sedangkan faktor ekstern, meliputi: (1) lingkungan keluarga, (2) lingkungan sekolah, (3) lingkungan masyarakat. ${ }^{5}$

Seperti yang kita ketahui, anak tuna grahita adalah anak yang memiliki inteligensi atau kecerdasan di bawah rata-rata 80-70, di SLB Waraqil Jannh ada beberapa anak yang menyandang ketuna grahitaan dan disertai dengan ketunaan lainnya atau kecacatan lainnya. Dari data sementara yang peneliti peroleh di SLB Waraqil Jannah tedapat 33 siswa bekebutuhan khusus. Diantara 34 siswa yang aktif ada beberapa siswa yang memiliki ketunaan lebih dari satu. Sebanyak 29 siswanya memiliki kecacatan ganda.

Berdasarkan data yang peneliti peroleh ada sekita 29 siswa dikelompokkan berdasarkan jenis disabilitasnya memperoleh hasil belajar dibawa KKM yang di tentukan yaitu 65. Hasil belajar ini dilihat dari nilai MID anak-anak di SLB Waraqil Jannah berdasarkan rombongan belajar. Rata-rata perolehan nilai anak disabilitas dan anak tuna grahita di SLB Waraqil Jannah memperoleh nilai berkisar dari niali yang paling rendah 30 sampai nilai paling tinggi yaitu 80 hanya ada beberapa anak yang memperoleh nilai di atas 65 dengan tngkat inteligensi antara 30 sampai 70.

${ }^{4}$ Muh. Misdar, "Mengkritisi Faktor-Faktor Kegagalan Akademik Siswa dalam belajar," Tadrib: Jurnal Pendidikan Agama Islam 4, no. 2 (2019), hlm. 206.

${ }^{5}$ Amilda dan Mardiah Astuti, Kesulitan Belajar (Yogyakarta: Pustaka Felicha, 2012), hlm. 8. 
Berdasarkan yang telah peneliti paparkan di atas, jika dikaitkan dengan faktor-faktor yang mempengaruhi hasil belajar pendidikan agama Islam pada anak tunagrahita,sangat penting untuk diperhatikan dikarenakan pendidikan keagamaan yang diberikan pada anak tunagrahita berbeda dengan pendidikan agama yang diberikan pada anak normal lainnya. Melihat kondisi tersebut maka peneliti tertarik mengangkat permasalahan ini dengan judul "Analisis Faktor-Faktor Yang Mempengaruhi Hasil Belajar Anak Tunagrahita Pada Mata Pelajaran Pendidikan Agama Islam Di SLB Waraqil Jannah Kec. X KotoPaninjauan Sumatera Barat”.

\section{METODE PENELITIAN}

Metodologi penelitian adalah proses atau cara ilmiah untuk memperoleh data yang akan digunakan untuk keperluan penelitian. Terdapat beberapa cara untuk melakukan penelitian. Di antaranya, populasi, sampel, jenis dan sumber data, teknik pengumpulan data dan teknik analisis data. Metode penelitian yang digunakan adalah metode deskriptif. Hal ini digunakan untuk mendapatkan sebuah gambaran mengenai masalah yang menjadi fokus penelitian penulis. Fokus penelitian ini adalah pada faktor-faktor dominan yang mempengaruhi hasil belajar pada mata pelajaran pendidikan agama Islam di SLB Waraqil Jannah. penelitian ini menggunakan pendekatan kuantititatif dimana data penelitian berupa angka dan analisis data bersifat statistik. Angka yang dihasilkan dari data yang dikumpulkan dilapangan dijadikan dalam bentuk persentase. Sehingga dapat mempermudah dalam menyajikan data. Teknik pengambilan sampel yang peneliti pilih yaitu Nonprobability Sampling dengan tehnik sampling Samling jenuh melihat jumlah populasi penelitian kurang dari 30 orang.

Jenis penelitian ini menggunakan penelitian kuantitatif deskriptif. Pendekatan yang digunakan peneliti adalah kuantitatif. Menurut Sugiyono dalam bukunya yang berjudul Metode Penelitian Pendidikan (Pendekatan kuantitatif, kualitatif dan $R \& D)$ menjelaskan metode kuantitatif diartikan sebagai metode penelitian yang berlandaskan pada filsafat positivisme, digunaan untuk meneliti pada populasi atau sampel tertentu, teknik pengambilan sampel pada umumnya dilakukan secara random, pengumpulan data menggunakan instrumen penelitian 
analisis data bersifat kuantitatif/statistik dengan tujuan untuk menguji hipotesis yang telah diterapkan. ${ }^{6}$

Dalam pengumpulan data, peneliti menggunakan teknik pengumpulan data dengan angket yang dibacakan langsung oleh peneliti dan dokumentasi sebagai pendukung dalam penelitian ini. selanjutnya data yang telah diperoleh akan dianalisis menggunakan metode statistik yang telah tersedia, dalam hal ini peneliti menggunakan rumus Chi Square atau yang lebih dikenal dengan rumus Kai Kuadrat untuk melihat pengaruh jenis disabilitas, tingkat inteligensi dan motivasi belajar anak tunagrahita terhadap hasil belajar pada mata pelajlajaran pendidikan agama Islam di SLB Waraqil Jannah. Harga Kai Kuadrat yang diperoleh adalah harga Kai Kuadrat yang merupakan angka persentase. Karena itu sebelum di interpretasi terhadap Kai Kuadrat, harus diubah terlebih dahulu kedalam bentuk frekuensi. ${ }^{7}$ Adapun rumus chi square yang digunakan sebagai berikut :

$$
\mathrm{x}_{\mathbf{0}}^{2}=\mathrm{x}_{\%}^{2} \mathrm{x} \frac{\mathrm{N}}{\mathbf{1 0 0}}
$$

Dengan dasar rumus di atas, maka dapat diperoleh nilai kai kuadrat dalam bentuk persentase yang selanjutnya akan digunakan untuk melihat persentase perbandingan pengaruh jenis disabilitas, tingkat inteligensi dan motivasi belajar terhadap hasil belajar anak tunagrahita dan tunagrahita ganda.

\section{HASIL DAN PEMBAHASAN}

Pada penelitian yang berjudul "Analisis Faktor-Faktor yang Mempengaruhi Hasil Belajar Anak Tuna Grahita pada Mata Pelajaran Pendidikan Agama Islam di SLB Waraqil Jannah Kec.X Koto Kab. Tanah Datar Paninjauan Sumatera Barat”. peneliti memperoleh data jenis disabilitas anak, tingkat inteligensi, dan motivasi belajar anak tunagrahita dan tunagrahita ganda yang peneliti paparkan pada tabel berikut :

${ }^{6}$ Sugiyono, Metode Penelitian Pendidikan Pendekatan Kuantitatif, kualitatif, dan R\&D (Bandung: Alfabeta, 2015), hlm. 14.

${ }^{7}$ Anas Sudijono, Pengantar Evaluasi Pendidikan (Jakarta: Grafindo Prasada, 2015), hlm. 287. 
Tabel Jenis Disabilitas, Tingkat Inteligensi, Motivasi dan Hasil Belajar AnaK Tunagrahita SLB Waraqil Jannah

\begin{tabular}{|c|c|c|c|c|}
\hline No & $\begin{array}{c}\text { Jenis Disabilitas } \\
\mathbf{X}_{1}\end{array}$ & $\begin{array}{l}\text { IQ } \\
\mathbf{X}_{2}\end{array}$ & $\begin{array}{c}\text { Nilai } \\
\text { Motivasi } \\
\mathbf{X}_{\mathbf{3}}\end{array}$ & $\begin{array}{c}\text { Hasil } \\
\text { Belajar/ } \\
\text { Nilai MID } \\
\text { Y }\end{array}$ \\
\hline 1 & Downsyindrome,Tunagrahita & 35 & 51 & 40 \\
\hline 2 & Downsyindrome, Tunagrahita & 30 & 70 & 65 \\
\hline 3 & Downsyindrome, Tunagrahita & 34 & 51 & 40 \\
\hline 4 & Tunarungu, Tunagrahita & 65 & 53 & 65 \\
\hline 5 & Downsyindrome, Tunagrahita & 40 & 56 & 50 \\
\hline 6 & Tunalaras, Tunagrahita & 51 & 54 & 65 \\
\hline 7 & Downsyindrome, Tunagrahita & 51 & 55 & 50 \\
\hline 8 & Tunalaras, Tunagrahita & 40 & 65 & 55 \\
\hline 9 & Tunadaksa, Tunagrahita & 60 & 62 & 50 \\
\hline 10 & Downsyindrome, Tunagrahita & 71 & 55 & 40 \\
\hline 11 & Tunadaksa, Tunagrahita & 60 & 51 & 80 \\
\hline 12 & Downsyindrome, Tunagrahita & 40 & 52 & 45 \\
\hline 13 & Downsyindrome, Tunagrahita & 30 & 63 & 30 \\
\hline 14 & Tunagrahita & 30 & 64 & 40 \\
\hline 15 & Tunagrahita & 61 & 61 & 70 \\
\hline 16 & Tunagrahita & 51 & 60 & 70 \\
\hline 17 & Tunagrahita & 41 & 67 & 60 \\
\hline 18 & Tunagrahita & 37 & 55 & 55 \\
\hline 19 & Tunagrahita & 62 & 56 & 60 \\
\hline 20 & Tunagrahita & 42 & 63 & 67 \\
\hline 21 & Tunagrahita & 70 & 66 & 80 \\
\hline 22 & Tunagrahita & 50 & 59 & 60 \\
\hline 23 & Tunagrahita & 62 & 55 & 65 \\
\hline 24 & Tunagrahita & 30 & 63 & 40 \\
\hline 25 & Tunagrahita & 76 & 63 & 78 \\
\hline 26 & Tunagrahita & 51 & 62 & 55 \\
\hline 27 & Tunagrahita & 50 & 65 & 40 \\
\hline 28 & Tunagrahita & 50 & 67 & 67 \\
\hline 29 & Tunagrahita & 30 & 61 & 35 \\
\hline
\end{tabular}

Sumber Data: Dokumen SLB Waraqil Jannah Tahun 2018/2019

Berdasarkan tabel di atas bahwa jenis disabilitas ditetapkan sebagai $\mathrm{X}_{1}$ merupakan variabel pertama dari rumusan masalah pada penelitian ini, sedangkan untuk tingkat inteligensi terletak $\mathrm{X}_{2}$ dan merupakan variabel kedua dari rumusan masalah pada penelitian ini, dan untuk motivasi belajar di tetapkan sebagai $\mathrm{X}_{3}$ yang merupakan variabel ketiga dari rumusan masalah pada penelitian. Sementara itu untuk variabel Y merupakan hasil belajar anak tunagrahita dan tunagrahita ganda. 
Vol. 2, No. 1, (Januari 2020): 74-86

Data yang peneliti peroleh merupakan data langsung dari dokumen SLB Waraqil Jannah. Data jenis disabilitas peneliti memperolehnya dari file dokumen SLB Waraqil Jannah yang mana telah peneliti rangkum dalam bentuk tabel di atas untuk membedakan anak disabilitas tunagrahita dan tunagrahita ganda. Sedangkan untuk tingkat inteligensinya peneliti memperoleh dari dokumen sekolah dan dokumen berupa surat keterangan hasil tes Inteligensi siswa dari rumah sakit setempat. Sedangkan untuk data motivasi belajar peneliti memperolehnya dengan menyebarkan angket yang mana angket tersebut peneliti bacakan langsung kepada siswa mengingat siswa SLB Waraqil Jannah belum bisa membaca. Dan data hasil belajar merupakan nilai murni atau nilai asli dari hasil ujian MID atau ulangan harian.

\section{Jenis Disabilitas}

Penggunaan rumus Kai Kuadrat untuk mengetes perbedaan persentase jenis disabilitas anak tunagrahita terhadap hasil belajar pada mata pelajaran pendidikan agama Islam di SLB Waraqil Jannah di peroleh harga kai kuadrat seperti yang tertera pada tabel di berikut :

Tabel persentase hasil belajar anak tunagrahita ganda dan tunagrahita

\begin{tabular}{|c|l|c|c|c|c|}
\hline No & \multicolumn{1}{|c|}{ Nilai MID } & Tinggi & Sedang & Rendah & Total \\
\hline 1 & Tuna Grahita Ganda & 3 & 28 & 14 & 45 \\
\hline 2 & Tuna Grahita & 7 & 34 & 14 & 55 \\
\hline & Jumlah & 10 & 62 & 28 & 100 \\
\hline
\end{tabular}

Setelah memperoleh persentase hasil belajar anak tunagrahita berdaarkan jenis disabilitas langkah selanjutna adalah melakukan perhitungan untuk memperoleh harga kai kuadrat jenis disabilitas.

Tabel Perhitungan untuk memperoleh harga Kai Kuadrat dari data yang tertera pada tabel di atas.

\begin{tabular}{|c|c|c|c|c|c|}
\hline Sel & $\boldsymbol{f}_{\mathbf{0}}$ & $\boldsymbol{f}_{\boldsymbol{t}}$ & $\left(\boldsymbol{f}_{\mathbf{0}}-\boldsymbol{f}_{\boldsymbol{t}}\right)$ & $\begin{array}{c}\left(\boldsymbol{f}_{\mathbf{0}}\right. \\
\left.-\boldsymbol{f}_{\boldsymbol{t}}\right)^{\mathbf{2}}\end{array}$ & $\frac{\left(\boldsymbol{f}_{\mathbf{0}}-\boldsymbol{f}_{\boldsymbol{t}}\right)^{\mathbf{2}}}{\boldsymbol{f}_{\boldsymbol{t}}}$ \\
\hline 1 & 3 & 4,5 & $-1,5$ & 2,25 & 0,5 \\
\hline 2 & 28 & 27,9 & 0,1 & 0,01 & 0,00035 \\
\hline 3 & 14 & 12,6 & 1,4 & 1,96 & 0,15555 \\
\hline 4 & 7 & 5,5 & 1,5 & 2,25 & 0,40909 \\
\hline
\end{tabular}




\begin{tabular}{|c|c|c|c|c|c|}
\hline 5 & 34 & 34,1 & $-0,1$ & 0,01 & 0,00029 \\
\hline 6 & 14 & 15,4 & $-1,4$ & 1,96 & 0,12727 \\
\hline 7 & $\mathrm{~N}=100$ & & & & 1,19255 \\
\hline
\end{tabular}

Dari perhitungan tabel di atas diperoleh Kai Kuadrat sebesar 1,19255. Tetapi harus diingat bahwa kai kuadrat sebesar itu masih merupakan angka persentase. Karena itu sebelum diberikan interprestasi terhadap kai kuadrat, terlebih dahulu dubah kedalam bentuk angka frekuensi dengan menggukan rumus:

$$
\begin{aligned}
X_{0}^{2} & =X_{\%}^{2} \times \frac{N}{100} \\
& =1,19255 \times \frac{29}{100}=0,3458395
\end{aligned}
$$

Setelah memperoleh harga kai kuadrat, langka selanjutnya adalah memberikan nilai interprestasi terhadap kai kuadrat dengan memperhitungkan df atau db nya sebagai berikut :

$$
\text { Df atau db } \begin{aligned}
& =(\mathrm{c}-1)(\mathrm{r}-1) \\
& =(3-1)(2-0)=2
\end{aligned}
$$

Dengan nilai interprestasi menggunkan tabel Kai Kuadrat $\mathrm{df}=\mathrm{N}-\mathrm{Nr}=$ 29-2 =27 dan taraf signifikansi 5\% diperoleh dari tabel Kai Kuadrat sebesar 40,113, sedangkan pada taraf signifikansi $1 \%$ diperoleh dari tabel Kai Kuadrat sebesar 46,963. Maka diketahui bahwa harga Kai Kuadrat jauh lebih kecil pada tabel signifikansi $5 \%$ maupun $1 \%$ atau $40,113<1,19255<46,963$. Sehingga hipotesa Nol $\left(\mathrm{H}_{0}\right)$ diterima. Dengan demikian dapat dikatakan bahwa tidak terdapat perbedaan yang signifikan antara hasil belajar anak tunagrahita dan tunagrahita ganda. Karena itu dapat disimpulkan bahawa jenis disabilitas tidak mempengaruhi hasil belajar anak tunagrahita pada mata pelajaran pendidikan agama Islam di SLB Waraqil Jannah Padang Panjang.

\section{Tingkat Inteligensi}

Penggunaan rumus Kai Kuadrat untuk mengetes perbedaan persentase tingkat inteligensi anak tunagrahita terhadap hasil belajar pada mata pelajaran 
pendidikan agama Islam di SLB Waraqil Jannah di perloeh harga kai kuadrat seperti yang tertera pada tabel di berikut:

Tabel persentase tingkat inteligensi anak tuna grahita ganda dan tuna grahita

\begin{tabular}{|c|l|c|c|c|c|}
\hline No & \multicolumn{1}{|c|}{ Nilai MID } & Tinggi & Sedang & Rendah & Total \\
\hline 1 & Tuna Grahita Ganda & 14 & 24 & 7 & 45 \\
\hline 2 & Tuna Grahita & 7 & 34 & 14 & 55 \\
\hline & Jumlah & 21 & 58 & 21 & 100 \\
\hline
\end{tabular}

Setelah memperoleh persentase tingkat inteligensi anak tunagrahita berdaarkan tingkat inteligensi langkah selanjutna adalah melakukan perhitungan untuk memperoleh harga kai kuadrat tingkat inteligensi.

Tabel perhitungan untuk memperoleh

Harga Kai Kuadrat dari data yang tertera pada tabel di atas.

\begin{tabular}{|c|c|c|c|c|c|}
\hline Sel & $\boldsymbol{f}_{\boldsymbol{0}}$ & $\boldsymbol{f}_{\boldsymbol{t}}$ & $\left(\boldsymbol{f}_{\boldsymbol{0}}-\boldsymbol{f}_{\boldsymbol{t}}\right)$ & $\left(\boldsymbol{f}_{\boldsymbol{o}}-\boldsymbol{f}_{\boldsymbol{t}}\right)^{\mathbf{2}}$ & $\frac{\left(\boldsymbol{f}_{\mathbf{0}}-\boldsymbol{f}_{\boldsymbol{t}}\right)^{\mathbf{2}}}{\boldsymbol{f}_{\boldsymbol{t}}}$ \\
\hline 1 & 14 & 9,45 & 4,55 & 20,7025 & 2,1907407 \\
\hline 2 & 24 & 26,1 & $-2,1$ & 4,41 & 0,1689655 \\
\hline 3 & 7 & 9,45 & $-2,45$ & 6,0025 & 0,6351851 \\
\hline 4 & 7 & 11,55 & $-4,55$ & $-20,7025$ & 1,792424 \\
\hline 5 & 34 & 31,9 & 2,1 & 4,41 & 0,1382445 \\
\hline 6 & 14 & 11,55 & 2,45 & 6,0025 & 0,519696 \\
\hline 7 & $\mathrm{~N}=100$ & & & & 5,4452558 \\
\hline
\end{tabular}

Dari perhitungan tabel di atas diperoleh Kai Kuadrat sebesar 5,4452558. Tetapi harus diingat bahwa kai kuadrat sebesar itu masih merupakan angka persentase. Karena itu sebelum diberikan interprestasi terhadap kai kuadrat, terlebih dahulu dubah kedalam bentuk angka frekuensi dengan menggukan rumus:

$$
\begin{aligned}
X_{0}^{2} & =X_{\%}^{2} \times \frac{N}{100} \\
& =5,4452558 \times \frac{29}{100}=1,579124182
\end{aligned}
$$

Setelah memperoleh harga kai kuadrat, langka selanjutnya adalah memberikan nilai interprestasi terhadap kai kuadrat dengan memperhitungkan df atau db nya sebagai berikut :

$$
\text { Df atau db }=(\mathrm{c}-1)(\mathrm{r}-1)
$$




$$
=(3-1)(2-0)=2
$$

Dengan nilai interprestasi menggunkan tabel Kai Kuadrat df $=\mathrm{N}-\mathrm{Nr}=$ 29-2 =27 dan taraf signifikansi 5\% diperoleh dari tabel Kai Kuadrat sebesar 40,113, sedangkan pada taraf signifikansi $1 \%$ diperoleh dari tabel Kai Kuadrat sebesar 46,963. Maka diketahui bahwa harga Kai Kuadrat jauh lebih kecil pada tabel signifikansi 5\% maupun $1 \%$ atau $40,113<5,4452558<46,963$. Sehingga hipotesa $\mathrm{Nol}\left(\mathrm{H}_{0}\right)$ diterima. Dengan demikian dapat dikatakan bahwa tidak terdapat perbedaan yang signifikan antara tingkat inteligensi anak tunagrahita dan tunagrahita ganda.

\section{Motivasi Belajar}

Penggunaan rumus Kai Kuadrat untuk mengetes perbedaan persentase motivasi belajar anak tunagrahita terhadap hasil belajar pada mata pelajaran pendidikan agama Islam di SLB Waraqil Jannah di perloeh harga kai kuadrat seperti yang tertera pada tabel di berikut:

Tabel Persentase Motivasi Belajar Anak Tunagrahita Ganda dan Tunagrahita

\begin{tabular}{|c|l|c|c|c|}
\hline No & \multicolumn{1}{|c|}{ Nilai Motivasi } & Tinggi & $\begin{array}{c}\text { Sedang/ } \\
\text { Rendah }\end{array}$ & Total \\
\hline 1 & Tuna Grahita Ganda & 7 & 38 & 45 \\
\hline 2 & Tuna Grahita & 7 & 48 & 55 \\
\hline 3 & Jumlah & 14 & 86 & 100 \\
\hline
\end{tabular}

Setelah memperoleh persentase motivasi belajar anak tunagrahita berdasarkan hasil motivasi belajar langkah selanjutna adalah melakukan perhitungan untuk memperoleh harga kai kuadrat motivasi belajar.

Tabel perhitungan untuk memperoleh

harga Kai Kuadrat dari data yang tertera pada tabel di atas.

\begin{tabular}{|c|c|c|c|c|c|}
\hline Sel & $\boldsymbol{f}_{\boldsymbol{0}}$ & $\mathbf{f}_{\mathbf{t}}$ & $\boldsymbol{f}_{\boldsymbol{0}-\boldsymbol{f}_{\boldsymbol{t}}}$ & $\begin{array}{c}\left(\boldsymbol{f}_{\mathbf{0}}\right. \\
\left.-\boldsymbol{f}_{\boldsymbol{t}}\right)^{\mathbf{2}}\end{array}$ & $\frac{\left(\boldsymbol{f}_{\mathbf{0}}-\boldsymbol{f}_{\boldsymbol{t}}\right)^{\mathbf{2}}}{\boldsymbol{f}_{\boldsymbol{t}}}$ \\
\hline 1 & 7 & 6,3 & 0,7 & 0,49 & 0,0396825 \\
\hline 2 & 38 & 38,7 & $-0,7$ & 0,49 & 0,01266149 \\
\hline 3 & 7 & 7,7 & $-0,7$ & 0,49 & 0,05974025 \\
\hline 4 & 48 & 47,5 & 0,5 & 0,25 & 0,005263157 \\
\hline & $\mathrm{N}=100$ & & & & 0,117347379 \\
\hline
\end{tabular}


Dari perhitungan tabel di atas diperoleh Kai Kuadrat sebesar 0,117347379. Tetapi harus diingat bahwa kai kuadrat sebesar itu masih merupakan angka persentase. Karena itu sebelum diberikan interprestasi terhadap kai kuadrat, terlebih dahulu dubah kedalam bentuk angka frekuensi dengan menggukan rumus:

$$
\begin{aligned}
& X_{0}^{2}=X_{\%}^{2} \times \frac{N}{100} \\
& =0,117347379 \times \frac{29}{100}=0,034074513
\end{aligned}
$$

Setelah memperoleh harga kai kuadrat, langka selanjutnya adalah memberikan nilai interprestasi terhadap kai kuadrat dengan memperhitungkan df atau db nya sebagai berikut :

$$
\text { Df atau db } \begin{aligned}
& =(c-1)(r-1) \\
& =(2-1)(2-1)=1
\end{aligned}
$$

Dengan nilai interprestasi menggunkan tabel Kai Kuadrat $\mathrm{df}=\mathrm{N}-\mathrm{Nr}=$ 29-1 =2 dan taraf signifikansi 5\% diperoleh dari tabel Kai Kuadrat sebesar 41,337, sedangkan pada taraf signifikansi $1 \%$ diperoleh dari tabel Kai Kuadrat sebesar 48,278. Maka diketahui bahwa harga Kai Kuadrat jauh lebih kecil pada tabel signifikansi $5 \%$ maupun $1 \%$ atau $41,337<0,117347379<48,278$. Sehingga hipotesa Nol $\left(\mathrm{H}_{0}\right)$ diterima. Dengan demikian dapat dikatakan bahwa tidak terdapat perbedaan yang signifikan antara motivasi belajar anak tunagrahita dan tunagrahita ganda.

\section{KESIMPULAN}

Berdasarkan hasil penelitian yang telah dilakukan terhadap faktor-faktor yang mempengaruhi hasil belajar anak tunagrahita dan tunagrahita ganda pada mata pelajaran pendidikan agama Islam di SLB Waraqil Jannah Kec.X Koto Paninjauan Sumatera barat dapat di simpulkan sebagai berikut:

1. Dengan nilai interprestasi menggunkan tabel Kai Kuadrat df $=\mathrm{N}-\mathrm{Nr}=29-2$ $=27$ dan taraf signifikansi 5\% diperoleh dari tabel Kai Kuadrat sebesar 40,113, sedangkan pada taraf signifikansi $1 \%$ diperoleh dari tabel Kai 
Kuadrat sebesar 46,963. Maka diketahui bahwa harga Kai Kuadrat jauh lebih kecil pada tabel signifikansi 5\% maupun $1 \%$ atau $40,113<1,19255<46,963$. Sehingga hipotesa Nol $\left(\mathrm{H}_{0}\right)$ diterima. Dengan demikian dapat dikatakan bahwa tidak terdapat perbedaan yang signifikan antara hasil belajar anak tunagrahita dan tunagrahita ganda. Karena itu dapat disimpulkan bahawa jenis disabilitas tidak mempengaruhi hasil belajar anak tunagrahita pada mata pelajaran pendidikan agama Islam di SLB Waraqil Jannah Padang Panjang.

2. Dengan nilai interprestasi menggunkan tabel Kai Kuadrat df $=\mathrm{N}-\mathrm{Nr}=29-2$ $=27$ dan taraf signifikansi 5\% diperoleh dari tabel Kai Kuadrat sebesar 40,113, sedangkan pada taraf signifikansi $1 \%$ diperoleh dari tabel Kai Kuadrat sebesar 46,963. Maka diketahui bahwa harga Kai Kuadrat jauh lebih kecil pada tabel signifikansi 5\% maupun $1 \%$ atau $40,113<5,4452558<46,963$. Sehingga hipotesa Nol $\left(\mathrm{H}_{0}\right)$ diterima. Dengan demikian dapat dikatakan bahwa tidak terdapat perbedaan yang signifikan antara tingkat inteligensi anak tunagrahita dan tunagrahita ganda. Karena itu dapat disimpulkan bahawa tingkat inteligensi tidak mempengaruhi hasil belajar anak tunagrahita pada mata pelajaran pendidikan agama Islam di SLB Waraqil Jannah Padang Panjang.

3. Dengan nilai interprestasi menggunkan tabel Kai Kuadrat df $=\mathrm{N}-\mathrm{Nr}=29-1$ $=2$ dan taraf signifikansi 5\% diperoleh dari tabel Kai Kuadrat sebesar 41,337, sedangkan pada taraf signifikansi $1 \%$ diperoleh dari tabel Kai Kuadrat sebesar 48,278. Maka diketahui bahwa harga Kai Kuadrat jauh lebih kecil pada tabel signifikansi 5\% maupun $1 \%$ atau $41,337<0,117347379<48,278$. Sehingga hipotesa Nol $\left(\mathrm{H}_{0}\right)$ diterima. Dengan demikian dapat dikatakan bahwa tidak terdapat perbedaan yang signifikan antara motivasi belajar anak tunagrahita dan tunagrahita ganda. Karena itu dapat disimpulkan bahawa motivasi belajar tidak mempengaruhi hasil belajar anak tunagrahita pada mata pelajaran pendidikan agama Islam di SLB Waraqil Jannah Padang Panjang. 


\section{DAFTAR PUSTAKA}

Amilda, dan Mardiah Astuti. Kesulitan Belajar. Yogyakarta: Pustaka Felicha, 2012.

Misdar, Muh. "Mengkritisi Faktor-Faktor Kegagalan Akademik Siswa dalam belajar." Tadrib: Jurnal Pendidikan Agama Islam 4, no. 2 (2019): 205-24.

Nur'aeni. Intervensi Dini Bagi Anak Bermasalah. Jakarta: Rineka Cipta, 2004.

Somantri, T. Sutjihati. Psikologi Anak Luar Biasa. Bandung: Redaksi Refika, 2006.

Sudijono, Anas. Pengantar Evaluasi Pendidikan. Jakarta: Grafindo Prasada, 2015.

Sugiyono. Metode Penelitian Pendidikan Pendekatan Kuantitatif, kualitatif, dan $R \& D$. Bandung: Alfabeta, 2015. 